\title{
The Effects of Moisture Damage on Asphalt Mixtures Modified with Additives and Polymer
}

\author{
Kesan Kerosakan Lembapan kepada Campuran Asphalt Terbubah bersama Bahan Tambahan dan Polimer
}

Akmal Othman, Ahmad Nazrul Hakimi Ibrahim, Naeem Aziz Memon \&

Nur Izzi Md. Yusoff*

\begin{abstract}
One of the causes of premature failure is moisture damage due to loss of adhesion and cohesion which then lead to stripping and decrease in mixture strength. Previous studies have shown that adding additive, such as nano clay, nano carbon and nano calcium, to binder is useful in enhancing mixture properties. In this study, the effect of adding nano-clay on mixture properties was determined. Nano clay in the amount of 2 and 4\% by weight of bitumen was added to 60/70 penetration grade bitumen and mixed at a temperature of $150^{\circ} \mathrm{C}$ using the melt blending technique at a shear rate of $2000 \mathrm{rpm}$. The indirect tensile strength (ITS) test was used to evaluate the cracking properties of the asphalt mixtures and the tensile strength ratio (TSR) was calculated to determine the degree of asphalt mixtures'resistance to moisture damage. The results for the mixtures modified with nano clay were compared with results for mixtures modified by adding 2 and $4 \%$ by weight of bitumen polymer modified bitumen (PG76), hydrated lime and cement. The addition of polymer appears to result in the greatest potential benefit amongst the modified binders and its highest TSR value indicate that polymer modified binder is the least susceptible to moisture damage.
\end{abstract}

Keywords: Nano-clay, polymer, moisture damage, indirect tensile strength

ABSTRAK

Salah satu sebab bagi kegagalan pramatang ialah kerosakan lembapan yang disebabkan oleh kemerosotan dalam lekatan dan kejelikitan yang seterusnya menyebabkan pelucutan dan menjejaskan kekuatan campuran asfalt. Kajian lalu menunjukkan bahawa penambahan bahan tambah seperti nanolempung, nanokarbon dan nanokalsium kepada pengikat berbitumen telah meningkatkan sifat campuran asfalt. Dalam kajian ini, nanolempung digunakan sebagai bahan tambah untuk menguji kesan terhadap sifat campuran panas asfalt (HMA). Proses pencampuran nanolempung sebanyak 2 dan $4 \%$ mengikut berat bitumen ke dalam bitumen gred penusukan $60 / 70$ dilakukan pada suhu $150^{\circ} \mathrm{C}$ dengan menggunakan kaedah pencampuran cair pada kadar putaran 2000 rpm. Ujian kekuatan tegangan tak langsung (ITS) digunakan untuk menguji rintangan retakan p campuran asfalt dan nisbah kekuatan tegangan (TSR) telah dihitung untuk menentukan tahap rintangan campuran HMA terhadap kerosakan lembapan. Keputusan yang diperoleh untuk nanolempung dibandingkan dengan keputusan untuk ujian campuran bitumen terubah suai polimer (PG76), kapur terhidrat dan simen dalam peratus yang sama, iaitu 2 dan 4\% mengikut berat bitumen. Keputusan ujian menunjukkan bahawa penambahan polimer menghasilkan keputusan positif dengan nilai TSR tertinggi berbanding bitumen terubah suai lain.

Kata Kunci: Nanolempung, polimer, kerosakan lembapan, kekuatan tegangan tak langsung.

\section{INTRODUCTION}

In recent decades, researchers have tried utilizing various types of additives to modify binder and improve road pavement resistance to damage (Al-Hadidy \& Tan 2009; Moghaddam \& Karim 2012; Sanchez-Alonso et al. 2013; Yao et al. 2012). In general, fibers and polymers are the two main materials used to modify bitumen. Fiber is one of the most common additives used to enhance the bond between bitumen and aggregate (Yao et al. 2012). Studies have proven that bituminous materials reinforced with fibers such as nylon fibers, carbon fibers and glass fibers could improve resistance against aging, cracking, fatigue and damage due to moisture (Yao et al. 2012).
Apart from fiber and polymer, hydrated lime and cement are also commonly used in the modification of bitumen. Hydrated lime is an active filler in bitumen. According to Little et al. (2001), the addition of materials has the beneficial effect of enhancing binder and asphalt mixtures' ability to resist deformation and cracking at low temperature. In addition, cement-based materials have been widely used for many years as composite materials for various types of structures. To reduce or control permanent deformation due to water damage, various studies have been conducted which have resulted in anti-stripping additives such as cement additives. These additives are used to enhance the physico-chemical properties of bitumen and aggregates (Behiry 2013). 
During the past decade nanotechnology has emerged as an alternative solution to improve the performance and durability of construction materials. Due to their small size and high surface area, the nature of nano-scale materials is very different from the nature of the ordinary sized materials. Several researches have been conducted and results of these researchers showed that the rutting and fatigue resistance of asphalt mixtures increased with the addition of nano materials (You et al. 2011). According to Liu (2007), the physical characteristics of bituminous binder can be improved when the polymer is modified with a small amount of nano-clay under nanoscopic conditions.

To deal with the problems related to the environmental factors in Malaysia, a study need to be conducted to find a way to increase the asphalt mixtures' resistance against moisture damage. Alternative methods should be identified to be used in the construction and maintenance of roads. This study was conducted to investigate the effect of adding materials such as nano-clay (NC), Portland cement (PC), hydrated lime (HL) and polymer modified bitumen on the performance of asphalt mixtures.

\section{MATERIALS AND EXPERIMENTAL DESIGN}

BINDER

The binder used in this study is $60 / 70$ penetration grade bitumen and its properties are presented in Table 1. It was found that the $60 / 70$ penetration grade bitumen used meet all the required specifications.

\section{POLYMER MODIFIED BINDER}

The climatic condition in countries such as Malaysia is fairly consistent throughout the country and the supply of performance graded (PG) binder in this region is based on the higher temperature. This study does not consider low temperature environment since the temperature in this country rarely falls below $30^{\circ} \mathrm{C}$ during daylight hours and usually range between $35-45^{\circ} \mathrm{C}$. A polymer-modified bitumen, PG-76, was used as a control sample and its physical and rheological properties are presented in Table 2 . The physical and rheological properties of PG-76 meet the minimum requirements as compared to the standard specifications.

TABLE 1. Properties of 60/70 penetration grade bitumen

\begin{tabular}{|c|c|c|c|c|}
\hline Binder Tests & Value & Unit & Specification & Method \\
\hline Penetration@25C & 63 & $0.1 \mathrm{~mm}$ & $60-70$ & ASTM D5 \\
\hline Softening Point & 47.2 & ${ }^{\circ} \mathrm{C}$ & 47 Min & ASTM D36 \\
\hline Ductility & $>100$ & $\mathrm{Cm}$ & $>100$ & ASTM D113 \\
\hline Specific Gravity@25 & 1.0354 & & $\mathrm{D}-70$ & ASTM D70 \\
\hline Flash Point & 318 & ${ }^{\circ} \mathrm{C}$ & 250 Min & D-92 \\
\hline Trichloroethylene Solution & 99.5 & $\mathrm{wt} \%$ & 99.5 Min & D-2042 \\
\hline Wax content & 1.84 & wt\% & 2.0 Max & DIN 52015 \\
\hline Loss of Ignition & 0.2 & wt\% & $0.2 \mathrm{Max}$ & D-5 \\
\hline Penetration Balance & 76.0 & $\%$ & 75 Min & D-5 \\
\hline
\end{tabular}

TABLE 2. Physical and rheological properties of PG-76

\begin{tabular}{|c|c|c|c|c|}
\hline Test & Unit & Result & Requirement & Test Standard \\
\hline \multicolumn{5}{|c|}{ Quality Specification } \\
\hline Softening Point & ${ }^{\circ} \mathrm{C}$ & 93 & $\operatorname{Min} 70^{\circ} \mathrm{C}$ & ASTM D36 \\
\hline Penetration & $0.1 \mathrm{~mm}$ & 46 & Min. 45 & ASTM D5 \\
\hline Flash Point & ${ }^{\circ} \mathrm{C}$ & 343 & $\operatorname{Min} 260^{\circ} \mathrm{C}$ & AASHTO T48 \\
\hline \multicolumn{5}{|c|}{ Performance Specification } \\
\hline Viscosity at $135^{\circ} \mathrm{C}$ & Pa.s & 2.45 & Max. 3 Pa.s & ASTM D4402 \\
\hline Dynamic shear, $\mathrm{G}^{*} / \sin \delta$ & $\mathrm{kPa}$ & 2.10 & Min 1.00 & AASHTO T315 \\
\hline Test temp@10 rad/s, 76C & & & $\mathrm{kPa}$ & \\
\hline \multicolumn{5}{|c|}{ Rolling Thin film Oven Test Residue (AASHTO T240) } \\
\hline Mass Loss & $\%$ & 0.04 & $\operatorname{Max} 1 \%$ & AASHTO T48 \\
\hline Dynamic shear, G*/sin $\delta$ & $\mathrm{kPa}$ & 3.40 & $\operatorname{Min} 2.20$ & AASHTO T315 \\
\hline Test temp@10 rad/s, 76C & & & $\mathrm{kPa}$ & \\
\hline \multicolumn{5}{|c|}{ Pressure Ageing Vessel Residue (AASHTO R28) } \\
\hline PAV Ageing Test Temperature & & & & \\
\hline Dynamic shear, $\mathrm{G}^{*} / \sin \delta$ & $\mathrm{kPa}$ & 1200 & Max. 5000 & AASHTO T315 \\
\hline Test temp@10 rad/s,37º C & & & $\mathrm{kPa}$ & \\
\hline
\end{tabular}


According to Sarsam (2013), the effect of binding the filler particles increase with the decrease in the particle size of the filler. Researchers in China have studied the effect of montmorillonite nano-clay on the copolymer properties of bitumen modified with styrene-butadiene styrene (SBS) by mixing the molten mixture with sodium montmorillonite (NaMMT) and organophilic montmorillonite (OMMT). The result of the study showed that the addition of Na-MMT and OMMT enhanced the viscosity SBS modified bitumen. In addition, the mixture showed a higher complex modulus and lower phase angle, which resulted in a tougher and more elastic bitumen. Therefore, asphalt mixtures modified with nano-clay could improve rutting resistance compared to unmodified bitumen (Polaccoa et al. 2008).

\section{HYDRATED LIME}

Limestone consists of calcium carbonate, $\mathrm{CaCO}_{3}$, and has a heating temperature of $980^{\circ} \mathrm{C}$ at which there is no carbon dioxide left and only hydrated lime $(\mathrm{CaO})$ is present. When water is added to the hydrated lime, it will expand and crack (Little et al. 2001). Adding hydrated lime to asphalt mixtures produce many benefits such as anti-stripping which could improve performance under heavy traffic load.

CEMENT

For many years cement-based materials have been widely used as composite materials in various types of structures. In order to reduce or control permanent deformation due to water damage. Various studies have been conducted which produced anti-stripping additives such as cement additives. These additives are used to enhance the physico-chemical properties of bitumen and aggregates to improve wetting by lowering the surface tension of bitumen (Behiry 2013). Portland cement is one of the additives used in this study.

\section{AGGREGATE PROPERTIES}

The aggregate used in this study was excavated from a mine located in Kajang, in the eastern part of the state of Selangor, Malaysia. The aggregate gradation was selected according to the ASTM D 3515-96 (D-5). The physical properties of the aggregates used was determined through several aggregate tests, namely Aggregate Crushing Value (ACV), Aggregate Impact Value (AIV), Flakiness Index (FI), Elongation Index (EI), Los Angeles Abrasion Value (LAAV) and Polished Stone Value (PSV). The results for all tests must be below the limit of the standard specifications. The specific gravity test for coarse and fine aggregates was conducted to measure the strength and quality of materials by determining the relative density and porosity of an aggregate in accordance with the BS 812: Part: 1975 standard.
A widely accepted test method known as the Modified Lottman test (AASHTO T283) was used to determine moisture susceptibility of asphalt mixes, and this method was adopted in the Superpave system. The AASHTO T283 test method is a better procedure than the immersion-compression test (ASTM D1075) or Marshall Immersion method since both these methods fail to effectively predict the moisture susceptibility of mixtures (Behiry 2013). The immersion compression test was introduced in the 1950s as the first moisture damage test on compacted samples under the ASTM standard. More recent attempts to develop a test to predict the moisture sensitivity of asphalt mixtures took place in the 1960s and 1970s with the work of Lottman (1978) and Schmidt and Graf (1972). The importance of simulating field condition by accelerating test conditions in the laboratory is generally acknowledged.

The specimens were placed between the steel loading strips using the UTM-25 in the indirect tensile test. Load was applied on specimen at a constant head rate of $50 \mathrm{~mm} / \mathrm{min}$ and the maximum compressive force was recorded until the specimen cracked. The ratio of the average tensile strengths of the conditioned (saturated) subset to the average tensile strength of the controlled (unconditioned) subset is the tensile strength ratio (TSR). Moisture sensitivity could be calculated using the following Equations 1 and 2:

$$
\mathrm{ITS}=2 \mathrm{P} / \pi \mathrm{LD}
$$

and

$$
\text { TSR }=\text { ITS }_{\text {(cond) }} / \text { ITS }_{\text {(dry) }}
$$

where ITS is tensile strength $(\mathrm{kPa}), \mathrm{P}$ is maximum load $(\mathrm{N})$, $\mathrm{L}$ is sample thickness $(\mathrm{mm}), \mathrm{D}$ is sample diameter $(\mathrm{mm})$, ITS $_{\text {cond }}$ is average tensile strength of the moisture-conditioned

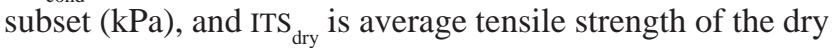
subset $(\mathrm{kPa})$.

\section{RESULTS AND DISCUSSION}

\section{AGGREGATE PROPERTIES ANALYSIS}

The physical properties of the aggregates used are presented in Table 3. The table shows that the aggregates used met all the requirement of the specifications. The selected gradation of the aggregate and the specific gravity values are presented in Table 4. The specific gravity values for both coarse and fine aggregates are between 2.53 and 2.64 and the specific gravity for the bitumen was taken as 1.03.

MOISTURE DAMAGE ANALYSIS

Moisture damage is among the most critical distresses exerted upon asphalt pavements. Moisture damage can be defined as a decrease in the values of asphalt mixtures' stiffness and strength durability caused by moisture (Yusoff et al. 2014). 
TABLE 3. Aggregate properties

\begin{tabular}{lccc}
\hline \multicolumn{1}{c}{ Aggregate test } & Result (\%) & Criteria (\%) & Method \\
\hline Aggregate Crushing Value (ACV) & 22.57 & $<30$ & BS 812: Part 110:1990 \\
Aggregate Impact Value (AIV) & 15.10 & $<30$ & BS 812: Part 110:1990 \\
Flakiness Index (FI) & 6.00 & $<20$ & BS 812: Section 105.1:1989 \\
Elongation Index (EI) & 12.00 & $<20$ & BS 812: Part 1:1975 \\
Los Angeles Abrasion Value (LAAV) & 32.13 & $<45$ & ASTM C: 131-81 \\
Polished Stone Value (PSV) & 45.00 & $>40$ & ASTM E303-93 \\
\hline
\end{tabular}

TABLE 4. Gradation of aggregates and their specific gravity (SG) values

\begin{tabular}{ccccc}
\hline \multirow{2}{*}{ Sieve Size } & \multicolumn{4}{c}{ Percent Passing (\%) } \\
\cline { 2 - 5 } & Upper Limit & Lower Limit & Design & SG $\left(\mathrm{g} / \mathrm{cm}^{3}\right)$ \\
\hline $12.5 \mathrm{~mm}$ & 100 & 90 & 95 & 2.63 \\
$9.5 \mathrm{~mm}$ & - & - & - & 2.64 \\
$4.75 \mathrm{~mm}$ & 74 & 44 & 59 & 2.64 \\
$2.36 \mathrm{~mm}$ & 58 & 28 & 43 & 2.54 \\
$300 \mu \mathrm{m}$ & 21 & 5 & 13 & 2.53 \\
$75 \mu \mathrm{m}$ & 10 & 2 & 6 & 2.64 \\
Dust & 2 & 0 & 1 & 2.65 \\
\hline
\end{tabular}

The water trapped in the coated aggregate might cause moisture damage, which then cause severe distresses on the pavement, such as stripping, localized bleeding, potholes, shoving and structural failure due to moisture intrusion into the asphalt pavements. The moisture damage test was conducted on all mixtures at the $\mathrm{OBC}$ for each individual mix.

The indirect tensile strength (ITS) values for unconditioned and conditioned mixtures are shown in Figure 1. The use of different type of additives showed varying values of ITS for both conditioned and unconditioned samples. Mixtures prepared with $2 \%$ of cement have the lowest ITS value for unconditioned sample while the addition of $4 \%$ of hydrated lime shows the lowest ITS value for conditioned samples. On the other hand, mixtures prepared with $2 \%$ HL have the highest ITS values before conditioning which is higher than the control mixture, and mixtures prepared with $2 \%$ NC has the highest ITS value after conditioning (higher than control mixtures).

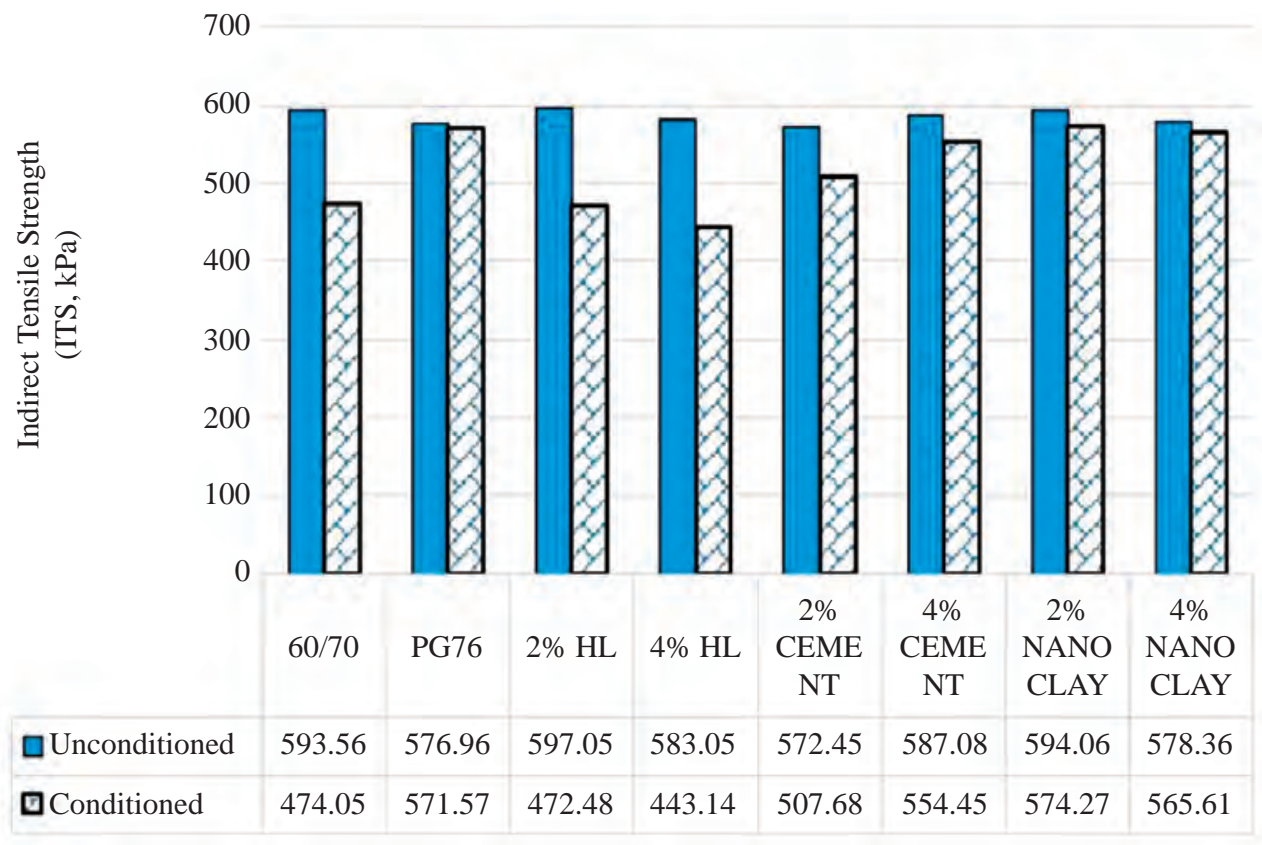

FIGURE 1. ITS values of unconditioned and conditioned mixtures 


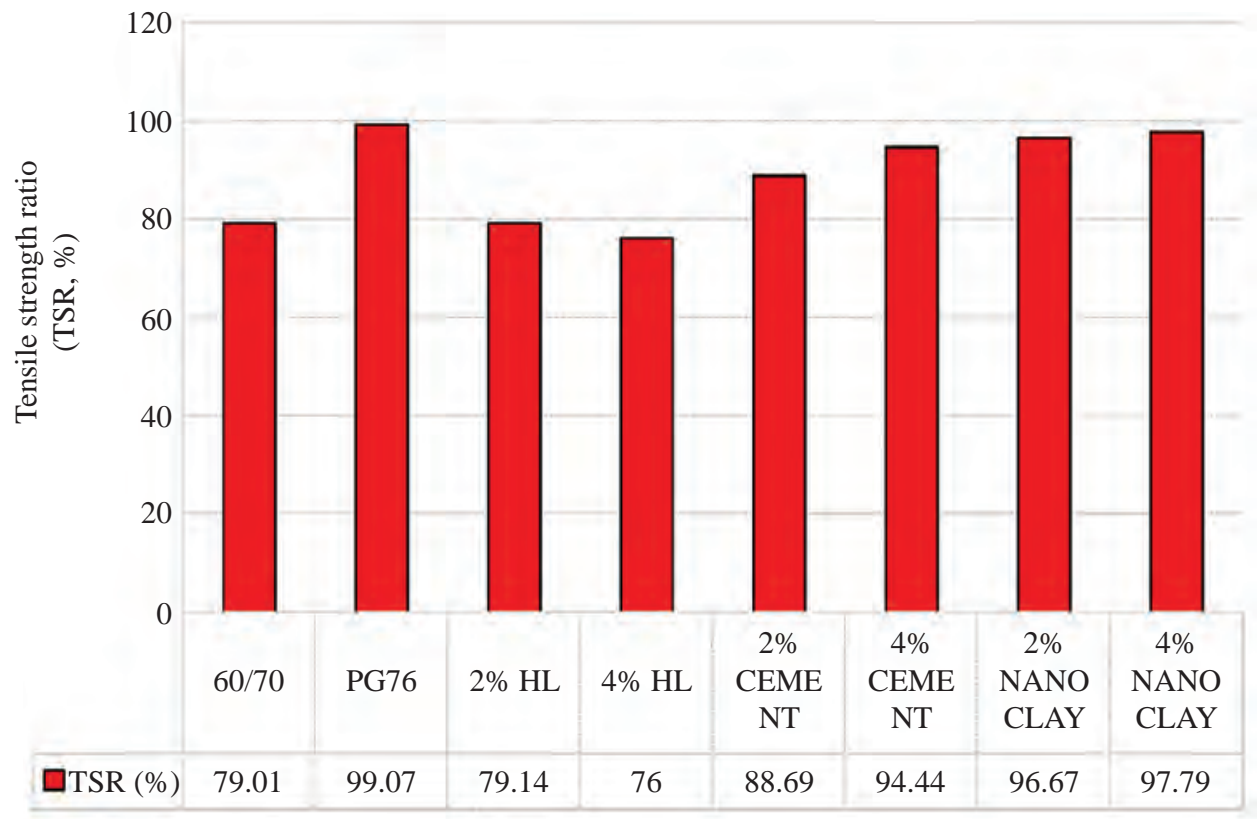

FIGURE 2. TSR values of mixtures

As can be seen in Figure 2, except for the mixtures prepared with hydrated lime and the control mixtures, all other mixtures meet the $80 \%$ lower limit on TSR value of Superpave specifications. The mixtures modified with polymer (PG76) is the least susceptible to moisture damage with a TSR of 99.07\% followed by mixtures with 4\% NC (97.79\%), 2\% NC (96.67), 4\% PC (94.44\%) and 2\% PC (88.69\%). This finding indicates that the strength of the asphalt mixtures increase with the addition of polymer.

\section{CONCLUSIONS}

Based on the laboratory work done in this study, it can be concluded that the addition of polymer could improve asphalt mixtures' performance against moisture damage. Similarly, the addition of NC also shows a great improvement in enhancing asphalt mixtures' resistance to moisture damage.

\section{ACKNOWLEDGEMENTS}

The authors would like to express their gratitude to the Department of Civil \& Structural Engineering, UKM for their cooperation and the information provided in ensuring the success of this study.

REFERENCES

Al-Hadidy, A. I. \& Tan, Y. Q. 2009. Mechanistic analysis of ST and SBS-modified flexible pavements. Construction and Building Materials 23(8): 2941-2950.

Behiry, A. E. A. E. M. 2013. Laboratory evaluation of resistance to moisture damage in asphalt mixtures. Ain Shams Engineering Journal 4(3): 351-363.
Little, D. N., Epps, J. A. \& Sebaaly, P. E. 2001. The benefits of hydrated lime in hot mix asphalt. National Lime Association.

Liu, P. 2007. Polymer modified clay minerals: A review. Applied Clay Science 38(1-2):.0 12 64-76.

Lottman RP. 1978. NCHRP Report 192: Predicting MoistureInduced Damage To Asphaltic Concrete. Washington, DC.

Moghaddam, T. \& Karim, M. 2012. Properties of SMA Mixtures Containing Waste Polyethylene Terephthalate. Proceedings of World Academy of Science 618-621.

Polaccoa, G., Kř́žz, P., Filippia, S., Stastnab, J., Biondia, D. \& Zanzotto, L. 2008. Rheological Properties of Asphalt/ SBS/Clay Blends. European Polymer Journal 44(11): 3512-3521.

Sanchez-Alonso, E., Vega-Zamanillo, A., Calzada-Perez, M. A. \& Castro-Fresno, D. 2013. Effect of warm additives on rutting and fatigue behaviour of asphalt mixtures. Construction and Building Materials 47: 240-244.

Sarsam, S. I. 2013. Nano Materials on Asphalt Cement Properties. International Journal of Scientific research in Knowledge (IJSRK) 1(10): 422-426.

Schmidt, R. \& Graf, P. 1972. The effect of water on the resilient modulus of asphalt treated mixes. Proceedings of the Association of Asphalt Paving Technologists 41: 118-125.

Yao, H., You, Z., Li, L., Shi, X., Goh, S. W., Mills-Beale, J. \& Wingard, D. 2012. Performance of asphalt binder blended with non-modified and polymer-modified nanoclay. Construction and Building Materials 35: 159-170.

You, Z., Mills-Beale, J., Foley, J. M., Roy, S., Odegard, G. M., Dai, Q. \& Goh, S. W. 2011. Nanoclay-modified asphalt materials: Preparation and characterization. Construction and Building Materials 25(2): 1072-1078. 
Yusoff, N. I. M., Breem, A. A. S., Alattug, H. N. M., Hamim, A. \& Ahmad, J. 2014. The effects of moisture susceptibility and ageing conditions on nano-silica/ polymer-modified asphalt mixtures. Construction and Building Materials 72: 139-147.

\section{Akmal Othman}

Ahmad Nazrul Hakimi Ibrahim

Nur Izzi Md. Yusoff ${ }^{1 *}$

Department of Civil and Structural Engineering

Faculty of Engineering and Built Environment

Universiti Kebangsaan Malaysia

43600 UKM Bangi

Malaysia

\section{Naeem Aziz Memon}

Department of Civil Engineering

Mehran University of Engineering and Technology

Jamshoro, Pakistan

*Corresponding author; email: izzi@ukm.edu.my 